\title{
Study of geo-hydrological processes and assessment of hazard and risk in the Banganga Watershed, Nepal
}

\author{
Motilal Ghimire \\ Central Department of Geography, Tribhuvan University, Kirtipur, Kathmandu, NEPAL
}

For correspondence.E-mail: motilal@wlink.com.np

Present study attempts to assess the nature of geo-hydrological hazards and risk in the Banganga watershed (27.69 to $27.75^{\circ} \mathrm{N}$ and 83.07 to $83.32^{\circ} \mathrm{E}$ ) in the western Nepal vis-à-vis the watershed's terrain, climatic geomorphic and socio-economic characteristics/processes. It also attempts to identify the hazard and risk areas based on the terrain relationship to the landslides incorporating the sites of gully and bank erosion, river shifting and flooding.

The information about the geo-hydrological events and their impacts, and the socio-economic characteristics of the watershed has been obtained from Participatory Rural Approach (PRA) and Rural Rapid Appraisal (RRA) methods. Similarly Geographic Information System (GIS) and the remote sensing techniques, the state-of-the art has been used for analysing the watershed terrain and assessing the hazard and risk. Topographic maps (1:25,000) prepared by the Topographic Survey Department in 1993 and the geological map $(1: 50,000)$ prepared by the Department of Mines and Geology in 1978, and the aerial photographs of 1978/79 and $1990(1: 50,000)$ produced by the Topographic Survey Department and the imageries obtained from Landsat Thematic Mapper (TM), 1998 were used for interpreting and analysing topography, drainage, geology and structure, geo-hydrological processes, and landuse/land cover changes. Substantial field verification of the map and photo/ imagery interpretation and observation/measurements including the PRA/RRA survey was carried out in October 1999.

The Banganga watershed (Figure 1) characterises the steep slopes (average slope $28^{\circ}$ ), narrow valley, steeper channel course ( $5.7^{\circ}$ for the Banganga River and $6.7^{\circ}$ for the Dhungre River), and fragile geology (the Siwaliks of Neogene age) occupy the southern half of the watershed. The remaining area beyond the Main Boundary Thrust is made of the Precambrian to Eocene Lesser Himalayan rocks comprising slate, shale, limestone, dolomite, sandstone and quartzite; these rocks are highly fractured consisting about three sets of joints (Aryal 1978). These factors have contributed to frequent slope movement and intense erosion processes during the heavy rainfall in monsoon. This is evidenced by widespread landslide scars, gully development, badland topography and large scale sedimentation in the narrow valleys. The topographic and geomorphic features reflect the marginality and susceptibility of the environment in terms of productivity and human habitat. The growing population pressure (3.5\% annual growth of households over the last 20 years) has been pressurizing the marginal ecosystem of the area. The expansion of the cultivated land (between 1954-1998, the cultivated land has increased by 2250 hectares i.e. $85 \%$ ) on the steep slopes $(71 \%$ increase in agricultural land on slopes of 15 $35^{\circ}$ ) either encroaching the forest area or shrub or grassland is evidence to this. The economy is characterised by the traditional agriculture of low productivity which has resulted in food shortage to more than $70 \%$ of the households. Due to adverse economic condition, the people of the watersheds are highly vulnerable to the geo-hydrological disasters caused by the landslides, gully erosion, bankcutting, river course shifting, debris torrents and flood.

In the watershed, active landslides have widely varying dimensions (up to $400 \mathrm{~m}$ long and wide up to $250 \mathrm{~m}$ ) and they are generally clustered. The chance of occurrence (Boots and Gettis 1988) of a new landslide within the distance of $500 \mathrm{~m}$ from any existing slide is 0.5 and that with $800 \mathrm{~m}$ is 1.0 . The sediments produced by landslides alone contribute to $14 \mathrm{~kg} / \mathrm{m}^{2} /$ year. Potentially unstable slopes were found in steep slopes, relatively high relief, in areas underlain by the shale and soft Siwalik sediments near to the lineaments and in the surface slope perpendicular or opposite to the dip direction of the bedding planes. Interestingly the slope movement phenomenon is high in the forest than in the cultivated land. The natural factors seem to have played predominant role in causing slope failures. The debris flows raise the bed level and lead to change in the river course on several reaches causing damage to agricultural land. Inundation is only during the rare high magnitude flood events and is limited to lower fan of Banganga River. The instantaneous impact of landslides and gully erosion is limited to not more than $2 \mathrm{~km}$ downstream.

The socio-economic significance of the hazard in the watershed is considerably high. There has been a significant loss of agricultural land and other infrastructure during the extreme geo-hydrological events. These events commonly recur at 10 years interval. The 24 hour maximum rainfall analysis shows that the recurrence interval of landslide triggering extreme rainfall, i.e. above $150 \mathrm{~mm}$ (Starkel 1972), in most meteorological stations around the watershed is about 5 years (Department of Hydrology and Meteorology 1975-98). This indicates that the potential threat from geo-hydrological disaster is quite frequent and risk is expected to increase with the growth of population and expansion of infrastructures.

The geo-hydrological hazard map (Varnes 1984, UNDRO 1991) (Figure 1) generated by GIS based bivariate statistical method (ILWIS 1997) has displayed high degree of reliability as overwhelming number of active and old landslides scars occur on high and very high hazard zone. This highly instable zone seems to be trending along the MBT. The hazard assessment shows that about $8 \%$ of the agricultural land is in high hazard areas. Similarly, 111 houses are located in the areas of high hazard and 211 houses in moderately high hazard areas and the rest $2152(85.9 \%)$ houses in the safe areas. And the risk map (UNDRO 1991) generated by combining the hazard map and the vulnerability map shows the $13 \%$ of area is under high risk.

The statistical relationship between the terrain parameters and landslide density is important for the development of the methodology for hazard zonation in the areas like the Banganga watershed where the landslides causing factors are widely varied and complex and are not well understood. The GIS and remote sensing technology has been successfully applied in the study. These techniques have been used for generating and analysing several terrain parameters and geo-hydrological hazard and risk 


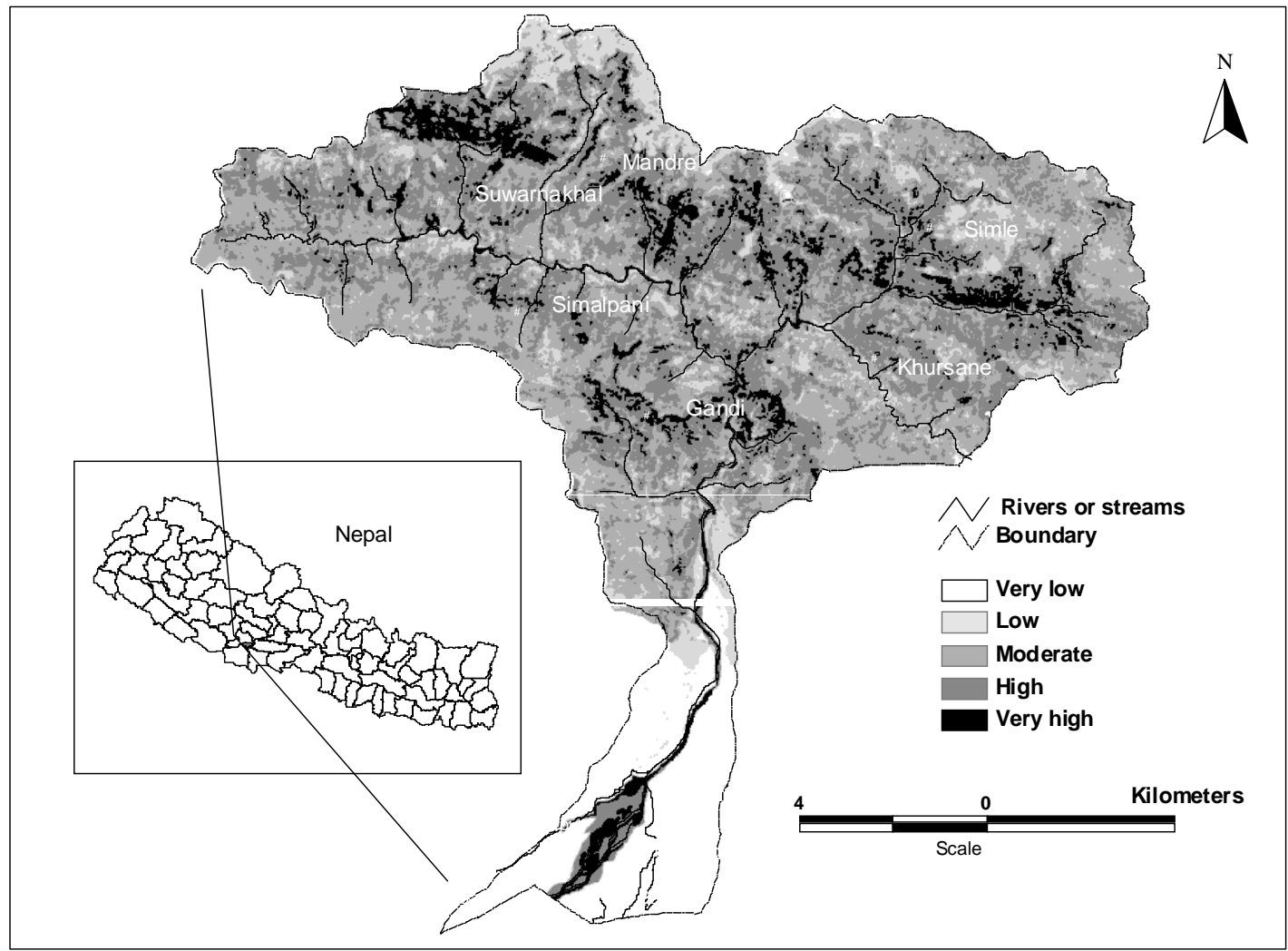

FIGURE 1. Geo-hydrological hazard map, the Banganga Watershed, western Nepal

assessment of the watershed. However, there is a scope to improve the result by using the imageries of higher resolution, and inclusion of more hazard parameters not used in the present study.

\section{References}

Aryal RK. 1978. Geological map of Lumbini Zone. Unpublished map and report submitted to the Department of Mines and Geology, Lainchaur, Kathmandu, Nepal

Boots BN and A Gettis. 1988. Analysing the spatial distributions of drumlins: a two mosaic approach. Jour Glaciology 6: 717-36

Department of Hydrology and Meteorology. 1975-1998. Climatic records of Nepal. DHM, Kathmandu.
Starkel L. 1972. The role of catestrophic rainfall in the shaping of the relief of the lower Himalaya (Darjeeling Hills). Geographia Polonica 21: 103-147 Survey Department, His Majesty's Government of Nepal. 1993. Topographic maps of Lumbini Zone. Produced in cooperation with the Japan International Cooperation Agency (JICA), 5 sheets: 098-05, 06, 07, 010 and 011)

The Integrated Land and Water Information System. ILWIS 1997 User's Guide. ILWIS Department, International Institute for Aerospace Survey and Earth Science Enschede, The Netherlands. p 419-420

UNDRO Office of the United Nations Disaster Relief Co-ordinator. 1991. Mitigation natural disasters: phenomena, effects and options. A manual for policy makers and planners, United Nations, New York, $164 \mathrm{p}$

Varnes DJ. 1984. Landslide hazard zonation: a review of principles and practices. Commision on Land slides of the IAEG, UNESCO, Natural Hazards No. $3.66 \mathrm{p}$ 